\title{
PERSEPSI MEREK DAN GAYA HIDUP \\ PEMAKAI TAS "CHANNEL" \\ (Studi Pada KonsumenOnline Shop)
}

\author{
Faiqotul Hima \\ Department of Management FEB UMM
}

\begin{abstract}
The purpose of this research is 1) To know and analyze the perception of consumers in the brand image (brand image) Channel bags and 2) To determine and analyze the lifestyle (lifestyle) Consumer Channel bag. The population in this study were all women in Malang who bought bags in the online shop, using judgmental sampling techniques can then be determined as many as 100 sample. The data analysis technique used in this research is the analysis of a range of scales.Based on the results of research and discussion that has been done, it can be concluded as follows: Consumer perception on brand image (brand image) bags Channel in the category brand catchy/recognizable, where the brand image (brand image) includes a unique logo, zipper logo chanel, stitch-patterned quilt (boxes), the price of comparable quality, have the serial number, made of calf leather and sheepskin, logo channel (2 c mesh), have the original card and rope chains of metal makes the consumer can easy to remember on Channel bag products. Perceptions on lifestyle (lifestyle) Consumer Channel bags can be obtained that the existence of the bag Channel can support activities, interests and opinions of consumers on the presence of products in the category Channel bag either. Lifestyle (lifestyle) consumer purse Channel can be seen that the respondents prefer to work outside the home, hobby of collecting bags, likes to shop, look for the latest fashion handbags. The consumer lifestyle can support recreational activities, family support on activities, knowledge, purchases of goods according to the needs and make the purchase because it becomes a habit.
\end{abstract}

Keywords: Brand image, Lifestyle, CHANNEL

\section{PENDAHULUAN}

Analisis terhadap perilaku konsumen yaitu mengenai analisis terhadap gaya hidup, yang merupakan salah satu indikator dari faktor pribadi yang turut berpengaruh terhadap perilaku konsumen. Gaya hidup menggambarkan seseorang secara keseluruhan yang berinteraksi dengan lingkungan. Gaya hidup juga mencerminkan sesuatu dibalik kelas sosial seseorang dan menggambarkan bagaimana mereka menghabiskan waktu dan uangnya.

Wanita sebagai salah satu objek dansubjek perkembangan trend dan fashion, merupakan objek pemasaran yang potensial bagi peritel fashion.Saat ini wanita digolongkan menjadi beberapa golongan, yakni wanita pekerja domestik dan wanita karir. Wanita memiliki kepekaaan 
dalam penggunaan berbagai sosial media yang mendukung proses untuk mendapatkan produk yang diharapkan, dimana salah satunya yaitu dengan menggunakan sosial media untuk melakukan transaksi yang akan dilakukan. Sosial media banyak digunakan untuk menawarkan produk-produk fashion, kecantikan, sepatu dan produk lainnya seperti tas.

Saat ini tas merupakan salah satu kebutuhan wanita. Di pasar brand beragam atau merek tas bisa menjadi pilihan wanita untuk menjalankan aktivitas pekerjaannya. Seiring perkembangan trend fashion tas memiliki variasi bentuk model serta warna. Salah satunya merek Channel meluncurkan tas untuk semua kebutuhan. Harga tas yang ditawarkan oleh desainer tas kelas dunia tersebut bervariasi dengan kisaran puluhan juta rupiah.Selain sebagai penunjang penampilan, tas juga mempengaruhi citra penggunanya.

Perkembangan social media secara tidak langsung mendukung menjamurnya online shop di Indonesia. Dimulai dengan kemunculan Facebook, Twitter hingga Instagram, online shop tidak lagi menjadi barang asing di Indonesia. Menurut (Susan\&Dann, 2011) online shop berasal dari kata Online yaitu aktifitas mengakses internet dan shopping yaitu belanja. Online shop adalah proses dimana konsumen membeli produk atau jasa melalui internet, yaitu melalui toko online yang ada di internet. Online shop telah banyak di facebook searah dengan semakin berkembangnya bisnis dan meningkatnya kebutuhan di masyarakat. Barang barang yang di jual hampir semua ada di facebook seperti pakaian, aksesoris, tas, buku, sepatu, dapat dijajakan dalam situs jejaring sosial tersebut.

Rumusan masalah dalam penelitian ini yaitu sebagai berikut: 1) Bagaimana persepsi konsumen terhadap merek (image)tas Channel? dan 2) Bagaimana gaya hidup (lifestyle)konsumen tas Channel?Penelitian ini diawali dengan penelitian sebelumnya yang dilakukan oleh Trista (2013). Metode analisis yang digunakan analisis regresi berganda. Adapun hasil penelitian tersebut yaitu citra merek dan kepercayaan merek yang dimiliki Toyota Avanza dapat di kategorikan baik. Citra merek dan kepercayaan merek berpengaruh positif signifikan terhadap pengambilan keputusan pembelian Toyota Avanza dikota Semarang dan citra merek mempunyai pengaruh dominan terhadap pengambilan keputusan pembelian.Surenda (2010), metode analisis yang digunakan analisis regresi berganda. Hasil analisis dapat diketahui bahwa gaya hidup berpengaruh positif signifikan terhadap keputusan pembelian Blackberry.Selain itu didukung oleh hasil penelitian Wisudawati (2014), hasil penelitian menunjukkan bahwa: (1) Citra merek berpengaruh positif dan signifikan terhadap keputusan wanita karir membeli Tas Hesmes tiruandengan koefisien regresi sebesar 0,179 artinya semakin kuat citra merek maka keputusan wanita karir membeli tas Hermes tiruan semakin tinggi; (2) Gaya hidup (Lifestyle ) berpengaruh positif dan signifikan terhadap keputusan wanita karir membeli Tas Hermes tiruandengan koefisien regresi sebesar 0,479 artinya semakin tinggi 
gaya hidup maka keputusan wanita karir membeli tas Hermes tiruan semakin tinggi; dan (3) Citra merek dan gaya hidup berpengaruh positif dan signifikan terhadap keputusan pembelian.

\section{TINJAUAN PUSTAKA}

Perilaku

konsumen

didefinisikan sebagai tindakan yang langsung terlibat dalam mendapatkan, mengkonsumsi, dan menghabiskan produk atau jasa, termasuk proses keputusan yang mendahului dan mengikuti tindakan ini. Dapat disimpulkan bahwa perilaku konsumen adalah semua kegiatan, tindakan, serta proses psikologis yang mendorong tindakan tersebut pada saat sebelum membeli, ketika membeli, menggunakan, menghabiskan produk atau jasa,setelah melakukan hal-hal di atas atau kegiatan mengevaluasi yang terjadi pada konsumen.

Merek

Merek adalah suatu nama, istilah, tanda, lambang, atau desain, atau gabungan semua yang diharapkan mengindentifikasi barang atau jasa dari seorang penjual atau sekelompok penjual, dan diharapkan akan membedakan barang atau jasa dari produk pesaing. Merek adalah suatu nama, kata, tanda, simbol atau desain atau kombinasi dari semuanya yang mengidentifikasikan pembuat atau penjual produk dan jasa tertentu (Kotler dan Amstrong (2004:349).Sedangkan menurut Kotler, (2002:22), merek adalah suatu nama, istilah, tanda, lambang, atau desain, atau gabungan semua yang diharapkan mengindentifikasi barang atau jasa dari seorang penjual atau sekelompok penjual, dan diharapkan akan membedakan barang atau jasa dari produk pesaing. Dari pengertian di atas dapat disimpulkan bahwa merek meliputi semua atribut sebagai tanda pembeda dari produk atau produsen lain yang mampu memberikan nilai yang dibutuhkan konsumen dan produsen.

Dalam penelitian ini dikatakan bahwa merek (brand) Channel merupakan sebuah tanda, simbol, dan desain yang dapat memberikan identitas terhadap sebuah tas, serta membedakan tas Channel dengan produk pesaingnya.

Dengan demikian dapat dikatakan bahwa unsur-unsur image di atas maka dapat dianalogikan suatu pernyataan sebagai berikut: image Channel yang melekat di ingatan konsumen adalah merek tas terkenal, memiliki desain yang berbeda dan mahal, lifestyle merujuk pada klasifikasi konsumen, sedangkan keputusan pembelian sebagai pilihan dan siap untuk melakukan pembelian atau penggunaan suatu barang.

Gaya Hidup

Adapun gaya Hidup secara luas didefinisikan sebagai cara hidup yang diidentifikasikan oleh bagaimana orang menghabiskan waktu mereka (aktivitas), apa yang mereka anggap penting dalam lingkungannya (ketertarikan), dan apa yang dipikirkan tentang diri merka sendiri dan juga dunia disekitarnya (pendapat).

Menurut Nugroho(2003:148) mendefinisikan gaya hidup secara luas sebagai cara hidup yang diidentifikasi oleh bagaimana orang menghabiskan waktu mereka (aktivitas) apa yang mereka anggap penting dalam lingkungannya (keterkaitan) dan apa yang mereka perkirakan tentang diri 
mereka sendiri dan dunia sekitarnya. Menurut Sunarto (2000:103), Gaya hidup atau lifestyle adalah pola kehidupan seseorang untuk memahami kekuatan-kekuatan ini kita harus mengukur dimensi activity, interest dan opinion (AIO). Dimensi activity (aktivitas) dilihat dari pekerjaan, hobi, belanja, olahraga, dan kegiatansosial. Sedangkan dimensiinterest(minat) terdiri dari makanan, mode, keluarga, rekreasi.
Dimensi opinion (pendapat) terdiri dari mengenai diri mereka sendiri, masalah-masalah sosial, bisnis, dan produk. Gaya hidup mencakup sesuatu yang lebih dari sekedar kelas sosial ataupun kepribadian seseorang.Penelitian ini bertujuan mengetahui pengaruh variabel independen yaitu merek dan gaya hidup pemakai tas Channel. Secara skematis,kerangka pemikiran penelitian ini digambarkan berikut ini.

\begin{tabular}{|l||l|}
\hline \multicolumn{1}{|c|}{ Merek(X1) } & \multicolumn{1}{|c|}{ Gaya Hidup(X2) } \\
1. Mudah dikenali \\
2. Reputasi yang baik \\
3. Selalu diingat.
\end{tabular}$\quad \begin{aligned} & \text { 2. Mktifitas. } \\
& \text { 3. Pendat. }\end{aligned}$

Gambar 1. Kerangka Pikir

Kerangka pikir merupakan alur penelitian yang akan dilakukan, dimana dalam penelitian hanya difokuskan pada merek dan gaya hidup agar dapat mencerminkan tingkat kepercayaan merek terhadap pemakai suatu produk yang akan dipakai atau dibeli oleh konsumen. Berdasarkan kerangka pikir penelitian maka dapat diketahui pemikiran konsumen terhadap merek (brand) dalam hal ini mudah dikenali, reputasi yang baik dan selalu diingat (Keller, 2009) dan gaya hidup (lifestyle) daam hal ini mengenai aktifitas, minat dan pendapat (Sunarto, 2000:103). Dalam penelitian ini akan dilakukan analisis terhadap merek dan gaya hidup dari pengguna tas merek Chanel.

\section{METODE PENELITIAN}

Penelitian ini dilakukan dari online Shop di Facebook yaitu di Chatelia Shop.Sesuai dengan judul penelitian yang di ambil, maka jenis penelitian yang dilakukan adalah penelitian survey, di mana peneliti melakukan observasi dalam pengumpulan data, peneliti hanya mencatat data seperti apa adanya, menganalisis dan menafsirkan data tersebut. Populasi dalam penelitian ini adalah seluruh wanita di Kota Malang yang membeli tas di online shop.Dalam penelitian ini pengambilan sampel menggunakan teknik judgmental sampling merupakan teknik non probability sampling dengan memilih orangorang yang terseleksi oleh peneliti berpengalaman berdasarkan ciri-ciri khusus dan dimiliki oleh sampel tersebut sehingga dipandang mempunyai sangkut paut yang erat dengan ciri-ciri khusus yang dimiliki sampel tersebut yang sudah diketahui sebelumnya (Singgih dan Fandy, 2000: 90).Sampel dalam penelitian ini adalah pembeli tas di online shop. 
Widayat (2012) menyatakan bahwa sampel harus berkaisar 30sampai 500. Maka jumlah sampel yang ditetapkan sebanyak 100 responden dianggap sudah mewakili.Analisis yang dilakukan dalam penelitian ini adalah analisis deskriptif kuatitatif, dengan menggunakan teknik analisis data yaitu:1) Rentang Skala, selanjutnya, dihitung juga skala interval jawaban responden, yang bertujuan untuk memudahkan interprestasi hasil, dengan rumus (Simamora 2004:220). 2) Skala, dalam pengukuran persepsi dengan skala Likert terdapat pertanyaan pertanyaa yang harus dijawab oleh responden. Bila mayoritas tanggapan responden adalah sangat setuju maka besarnya mean akan mendekati angka 5, sebaliknya bila tanggapan responden adalah sangat tidak setuju maka mean akan mendekati nilai angka 1 (dalam skala 1-5). Berdasarkan nilai maksimum dan minimum tersebut dapat diketahui bagaimana persepsi responden.

\section{HASIL PENELITIAN DAN PEMBAHASAN}

Hasil analisis rentang skala digunakan untuk menegtahui persepsi konsumen pada merek (brand) tas Channel dan gaya hidup (lifestyle)konsumen tas Channel, rentang skala diperoleh dengan melakukan perkalian dari masingmasing skor jawaban dengan skor jawaban responden. Dari hasil perhitungan maka akan dimasukkan kriteria yang telah ditetapkan dari hasil analisis rentang skala. Berdasarkan deskripsi jawaban responden maka hasil analisis rentang skala merek (brand) tas Channel yaitu sebagai berikut:

Tabel 1. Hasil Analisis Rentang Skala Merek $\left(\mathrm{X}_{1}\right)$

\begin{tabular}{|c|c|c|}
\hline Item & Skor & Kriteria \\
\hline \multicolumn{3}{|l|}{ Mudah dikenali } \\
\hline Logo yang unik $\left(\mathrm{X}_{1.1}\right)$ & 368 & Mudah dikenali \\
\hline Retsleting berlogo Chanel $\left(\mathrm{X}_{1.2}\right)$ & 366 & Mudah dikenali \\
\hline Jahitan bermotif quilt (kotak-kotak) $\left(\mathrm{X}_{1.3}\right)$ & 367 & Mudah dikenali \\
\hline Rata-rata & 367 & Mudah dikenali \\
\hline \multicolumn{3}{|l|}{ Reputasi } \\
\hline Harga sebanding kualitas $\left(\mathrm{X}_{1.4}\right)$ & 372 & Reputasi baik \\
\hline Memiliki serial number $\left(\mathrm{X}_{1.5}\right)$ & 380 & Reputasi baik \\
\hline $\begin{array}{l}\text { Dibuat dari kulit anak sapi dan kulit domba } \\
\left(\mathrm{X}_{1.6}\right)\end{array}$ & 367 & Reputasi baik \\
\hline Rata-rata & 373 & Reputasi baik \\
\hline \multicolumn{3}{|l|}{ Selalu Diingat } \\
\hline $\begin{array}{l}\text { Logo channel ( } 2 \text { huruf } C \text { yang bertautan) } \\
\left(\mathrm{X}_{1.7}\right)\end{array}$ & 257 & Cukup diingat \\
\hline Memiliki kartu asli $\left(\mathrm{X}_{1.8}\right)$ & 383 & Selalu Diingat \\
\hline Tali rantai dari logam $\left(\mathrm{X}_{1.9}\right)$ & 396 & Selalu Diingat \\
\hline Rata-Rata & 345 & SelaluDiingat \\
\hline Total Rata-rata & 362 & $\begin{array}{l}\text { Merek mudah dikenali, } \\
\text { memiliki reputasi yang } \\
\text { baik dan selalu diingat }\end{array}$ \\
\hline
\end{tabular}


Nilai rata-rata mengenai persepsi konsumen pada citra merek (brand image) tas Channel diperoleh skor sebesar 362 masuk dalam kategori selalu diingat. Hasil baik menunjukkan bahwa selama ini konsumen merasakan bahwa citra merek (brand image) yang baik atas tas channel yang meliputi logo yang unik, retsleting berlogo chanel, jahitan bermotif quilt (kotak-kotak), harga sebanding kualitas, memiliki serial number, dibuat dari kulit anak sapi dan kulit domba, logo channel (2 huruf c yang bertautan), memiliki kartu asli dan tali rantai dari logam.Berdasarkan deskripsi jawaban responden maka hasil analisis rentang skala gaya hidup (lifestyle)konsumen tas Channel yaitu sebagai berikut:

Tabel 2. Hasil Analisis Rentang Skala Gaya Hidup $\left(\mathrm{X}_{2}\right)$

\begin{tabular}{|c|c|c|}
\hline Item & $\begin{array}{l}\text { Skor Rentang } \\
\text { Skala }\end{array}$ & Kriteria \\
\hline \multicolumn{3}{|l|}{ Activity (Aktivitas) } \\
\hline Suka bekerja di luar rumah $\left(\mathrm{X}_{2.1}\right)$ & 318 & $\begin{array}{l}\text { Cukup mendukung } \\
\text { aktivitas }\end{array}$ \\
\hline Hobi mengoleksi tas $\left(\mathrm{X}_{2.2}\right)$ & 384 & Mendukung aktivitas \\
\hline Kesukaan untuk berbelanja $\left(\mathrm{X}_{2.3}\right)$ & 380 & Mendukung aktivitas \\
\hline Rata-rata & 361 & Mendukung aktivitas \\
\hline \multicolumn{3}{|l|}{ Interest (Minat) } \\
\hline Mencari tas mode terbaru $\left(\mathrm{X}_{2.4}\right)$ & 367 & Mendukung minat \\
\hline Mendukung aktivitas rekreasi $\left(\mathrm{X}_{2.5}\right)$ & 378 & Mendukung minat \\
\hline $\begin{array}{l}\text { Keluarga mendukung atas aktivitas } \\
\left(\mathrm{X}_{2.6}\right)\end{array}$ & 356 & Mendukung minat \\
\hline Rata-rata & 367 & Mendukung minat \\
\hline \multicolumn{3}{|l|}{ Opinion (Pendapat) } \\
\hline Pengetahuan $\left(\mathrm{X}_{2.7}\right)$ & 352 & Pendapat yang baik \\
\hline $\begin{array}{l}\text { Pembelian barang sesuai kebutuhan } \\
\left(\mathrm{X}_{2.8}\right)\end{array}$ & 371 & Pendapat yang baik \\
\hline Membeli menjadi kebiasaan $\left(\mathrm{X}_{2.9}\right)$ & 300 & Pendapat cukupbaik \\
\hline Rata-Rata & 341 & Pendapat yang baik \\
\hline Total Rata-Rata & 356 & $\begin{array}{l}\text { Mendukung aktivitas, } \\
\text { minat dan memiliki } \\
\text { pendapat yang baik }\end{array}$ \\
\hline
\end{tabular}


Nilai rata-rata gaya hidup (lifestyle)konsumen tas Channel diperoleh nilai sebesar 356yang masuk dalam kriteria mendukung aktivitas, minat dan memiliki pendapat yang baik. Kondisi ini menunjukkan bahwa gaya hidup (lifestyle)konsumen tas Channel adalah baik dalam hal ini yaitu mengenai Suka bekerja di luar rumah, hobi mengoleksi tas, kesukaan untuk berbelanja, mencari tas mode terbaru, mendukung aktivitas rekreasi, keluarga mendukung atas aktivitas, pengetahuan, pembelian barang sesuai kebutuhan dan melakukan pembelian karena menjadi kebiasaan.

Hasil analisis mengenai persepsi konsumen pada merek (brand) tas Channel diperoleh skor sebesar 362 masuk dalam kategori selalu diingat. Persepsi baik tersebut menunjukkan bahwa selama ini konsumen merasakan bahwa merek (brand) yang baik atas tas channel yang meliputi logo yang unik, retsleting berlogo chanel, jahitan bermotif quilt (kotak-kotak), harga sebanding kualitas, memiliki serial number, dibuat dari kulit anak sapi dan kulit domba, logo channel (2 huruf c yang bertautan), memiliki kartu asli dan tali rantai dari logam.Merek (brand) tas Channel yang selalu diingat tersebut dapat memberikan gambaran mengenai keunggulan yang dimiliki oleh produk sehingga produk selalu diingat oleh konsumen.

Hasil penelitian didukung oleh teori yang dikemukakan oleh Keller (2009) yang menyatakan merek yang memiliki merek didalam pikiran konsumen cenderung memberikan kontribusi yang lebih penting terhadap kesuksesan sebuah merek dibanding karakteristik aktual yang dimiliki merek, sehingga pemasar berusaha untuk menciptakan citra merek (brand image)atauproduk yang konsisten dengan citra diri konsumen yang kira-kira sesuai pada segmen pasar yang ditargetkan. Indikatoryang mencerminkan keberadaan citra merek dirangkum oleh yaitu:mudah dikenali, reputasi yang baik dan selalu diingat.

Hasil analisis mengenaigaya hidup (lifestyle )konsumen tas Channel diperoleh nilai sebesar 356 yang masuk dalam kriteria mendukung aktivitas, minat dan memiliki pendapat yang baik. Kondisi ini menunjukkan bahwa gaya hidup (lifestyle) konsumen tas Channel adalah baik dalam hal ini yaitu mengenai Suka bekerja di luar rumah, hobi mengoleksi tas, kesukaan untuk berbelanja, mencari tas mode terbaru, mendukung aktivitas rekreasi, keluarga mendukung atas aktivitas, pengetahuan, pembelian barang sesuai kebutuhan dan melakukan pembelian karena menjadi kebiasaan. Jadi keberadaan produk mendukung dan sesuai dengan gaya hidup (lifestyle)konsumen tas Channel.

Gaya hidup penguna tas mode atau tas branded kini tak hanya menjual tas wanita namun kini tas mode atau tas branded juga menjadi tempat para wanita sosialita yang ingin melihat tren tas model terbaru hari ini atau yang sedang ramai digunakan. Tas yang digunakan dapat memberikan daya tarik wanita yang menggunakannya, bagi pengguna tas bermerek akan memberikan dukungan dalam upaya untuk menciptakan kepercayaan dan dukungan dalam rangka mendukung penampilannya. Gaya hidup yang 
dimiliki para pengguna tas bermerek juga mencerminkan tingkat kepercayaan diri para penggunanya sehingga dengan gaya hidup yang mengikuti perkembangan produk tas menjadi jaminan bahwa produk yang digunakan benar-benar mampu mendukung aktivitas rutin yang dilakukan.

Hasil penelitian ini mendukung pendapat Sunarto (2000:103) bahwa gaya hidup atau lifestyle adalah pola kehidupan seseorang untuk memahami kekuatan-kekuatan ini kita harus mengukur dimensi activity, interest dan opinion (AIO).Dimensi activity (aktivitas) dilihat dari pekerjaan, hobi, belanja, olahraga, dan kegiatansosial. Sedangkan dimensiinterestminat) terdiri dari makanan, mode, keluarga, rekreasi. Dimensi opinion (pendapat) terdiri dari mengenai diri mereka sendiri, masalah-masalah sosial, bisnis, dan produk. Gaya hidup mencakup sesuatu yang lebih dari sekedar kelas sosial ataupun kepribadian seseorang.

Berdasarkan hasil penelitian dan pembahasan yang telah dilakukan maka dapat ditarik kesimpulan sebagai berikut: 1) Persepsi konsumen pada merek (brand) tas Channel masuk dalam kategori merek yang mudah diingat/ dikenali, dimana merek (brand) meliputi logo yang unik, retsleting berlogo chanel, jahitan bermotif quilt (kotak-kotak), harga sebanding kualitas, memiliki serial number, dibuat dari kulit anak sapi dan kulit domba, logo channel (2 huruf c yang bertautan), memiliki kartu asli dan ali rantai dari logam menjadikan konsumen dapat dengan mudah mengingat atas produk tas Channel.
2) Persepsi pada gayahidup (lifestyle) konsumen tas Channel dapat diperoleh hasil bahwa keberadaan tas Channel dapat mendukung aktivitas, minat dan pendapat konsumen atas keberadaan produk tas Channel masuk dalam kategori baik. Gayahidup (lifestyle) konsumen tas Channel dapat diketahui bahwa respondensuka bekerja di luar rumah, hobi mengoleksi tas, kesukaan untuk berbelanja, mencari tas mode terbaru. Gaya hidup konsumen tersebut dapat mendukung aktivitas rekreasi, keluarga mendukung atas aktivitas, pengetahuan, pembelian barang sesuai kebutuhan dan melakukan pembelian karena menjadi kebiasaan.

\section{SIMPULAN}

Perusahaan harus tetap menjaga reputasi dari produk tas Channel sehingga konsumen benarbenar selalu mengingat bahwa merek tersebut merupakan produk yang memiliki jaminan kualitas produk yang tinggi sehingga mindshare konsumen akan menilai bahwa produk tas Channel mudah dikenali karena memiliki reputasi yang baik. Perusahaan harus mempertahnkan citra merek dari produk tas Chanel sehingga mendukung upaya perusahaan untuk mempengaruhi konsumen untuk melakukan pembelian produk sehingga dapat mendukung aktivitas yang dilakukan oleh konsumen.

\section{DAFTAR PUSTAKA}
A.B. Susanto dan Himawan Wijanarko, 2004, Power Branding, Jakarta : Quantum Bisnis dan Manajemen. 
Alma, Buchari, 2005. Manajemen Pemasaran Dan Pemasaran Jasa, Bandung: CV. Alfabeta.

Bilson Simamora, 2003, Panduan Riset Perilaku Konsumen, Penerbit PT. Gramedia Pustaka Utama, Jakarta.

Dann, Susan \& Stephen Dann. 2001. Strategic Internet Marketing. Melbourne: John Willey \& Sons A ustralia. LTD.

Ermanza, Gita Handayani, 2007, Hubungan antara Harga Diri dan Citra Tubuh pada Remaja Putri yang Mengalami Obesitas dari Sosial Ekonomi Menengah.

Fandy, Tjiptono, 2005, Strategi Pemasaran. Edisi Kedua, Cetakan Pertama, Penerbit Andi Offset. Yogyakarta.

Henry Simamora, 2000, "Pemasaran", Edisi Kedua, UPP AMP YKPN

Kasali, Rhenald. 2001. Membidik Pasar Indonesia Segmentasi Targeting Positioning Jakarta: PT Gramedia Pustaka Utama

Kevin Lane Keller., 2003, Strategic Brand Manajemen, Second Edition, Prentice Hall Kotler, Philip, 2005, Manajemen Pemasaran: Perencanaan, Implementasi dan Pengendalian, Prehallindo: Jakarta.

Kotler, Philip dan Keller, Kevin Lane. 2008. Manajemen Pemasaran. Edisi 12. Jilid 2. PT Indeks. Jakarta.

Kotler, Philip dan Gary Amstrong ,2009, Dasar-Dasar Pemasaran, Edisi Kesembilan, Jilid 1, Penerbit PT. Indeks Kelompok Gramedia: Jakarta.
Lamb, Charles W; Joseph F. Hair; dan Carl McDaniel. 2001. Pemasaran.. Alih Bahasa.

Masri Singarimbun\& SofyanEffendi, 1995, Metode Penelitian Survei, Edisi. Revisi, PT. Pustaka LP3ES

Nadia Lona Trista, 2013, Pengaruh citra merek dan kepercayaan merek terhadap pengambilan keputusan pembelian Toyota Avanza dikota Semarang, Skripsi Universitas Sebelas Maret.

Rian Surenda, 2010, Pengaruh gaya hidup terhadap keputusan pembelian Blackberry" tentang keputusan pembelian Blackberry, Skripsi Universitas Muhammadiyah Malang.

Setiadi, Nugroho J. 2003, Perilaku Konsumen. Kencana. Jakarta.

Sunarto., 2003, Akuntansi Biaya, Edisi Revisi, AMUS, Yogyakarta.

Sugiyono, 2004, Metode Penelitian Bisnis, CV. Alfabeta, Bandung, 2012, Metode Penelitian Bisnis, Cetakan Ketujuh , Penerbit Alfabeta CV, Bandung.

Supardi.2005. Metode Penelitian Ekonomi dan Bisnis. Yogyakarta: UII Press. Suryabrata

Suharsimi Arikunto, 2006, Prosedur Penelitian, Edisi Revisi Keempat. Penerbit Cipta, Jakarta. Wisudawati, 2014, Pengaruh citra merek dan gaya hidup terhadap keputusan pembelian tas Hermes tiruan pada wanita karir, Skripsi Universitas Airlangga. 